\title{
The Critical Success Factors for Implementation of Electric Customer Relationship Management in the Commercial Bank of Viet Nam
}

\author{
Thuy Van Nguyen ${ }^{1} \&$ Cuong Hung Pham ${ }^{2}$ \\ ${ }^{1}$ Banking Academy of Viet Nam, Ha Noi, Vietnam \\ ${ }^{2}$ Foreign Trade University, Ho Chi Minh City Campus, Vietnam \\ Correspondence: Thuy Van Nguyen, Banking Academy of Viet Nam, Ha Noi, Vietnam.
}

Received: July 15, 2016

doi:10.5430/ijfr.v7n5p124
Accepted: August 11, 2016

Online Published: October 8, 2016

URL: http://dx.doi.org/10.5430/ijfr.v7n5p124

\begin{abstract}
In the context of globalization and international economic integration currently, competitive pressure from the requirements of customers for banking product and services are increasing. Banks must increase investment in technological applications, built and develop modern infrastructure to diversify the banking products and services, in which the most flourishingsector is electronic banking services. Implementing successfully Electric Customer Relationship Managemet - eCRM solutions banks are expected to be the optimal solution increasing ability to understand and approaching customers better, thereby improving the bank's competitiveness. However, successful rate of implementing eCRM in world as well as in Vietnam is not high. Banks implemented eCRM often have not achieved success as expected. This study identifies and quantifies the factors that affect the success of eCRM implement of commercial banks in Vietnam, then propose solutions helping banks implement successfully eCRM solutions, improving competitive competence of commercial banks in Vietnam today.
\end{abstract}

Keywords: customer relationship management (CRM), eletric customer relationship management (eCRM), electric banking (e-banking), social customer relationship management (sCRM), critical success factors (CSF), efficiency of customer relationship

\section{Introduction}

Famous economist Erwin FRAND stated that "Every company's greatest assets are its customers, because without customers there is no company" this statement shows the role of customers in all business activities, is the factor determining success of business. The question now is how to use technology, people, management processes in an optimal way in order to capture the essence of customers' interests, behavior, value. From there, they can come up with the best goods and service to meet customers' demands. Long time ago, in over the world, customer relationship management - CRM is mentioned as an effective solution which help administrators solve these above issues. CRM is a broad field which many scholars and administrators interested in, research and develop. CRM is strategy attracting and maintaining customers by focusing company's resources on supplying products, services and customers care. CRM help businesses approach and communicate with customers in a systematic, effective manner. CRM manages comprehensively information about customer, serve overall targets, seek for new customers, maintain existing customers, entice former clients back, create good and long-term relationships with clients. In view of the business strategy oriented customers:"CRM is a set of strategic activities aims at selecting, establishing, maintaining and developing good and long term relationships between businesses and customers on the basis of adapting the processes to create interests of consumers and businesses ".

Along with the advancement of information communications technology, establishing of Internet and Web 2.0 technology promotes the development of e-commerce. The concept of CRM in the context that e-commerce becomes eCRM (Electric Customer Relationship Management). According to Pan and Lee (2003) "Taking advantage of the revolutionary impact of the Internet, e-CRM expands the traditional CRM techniques by integrating technologies of new electronic channels, such as Web, wireless, and voice technologies, and combines them with e-business applications into the overall enterprise CRM strategy". eCRM increases ability to capture, integrate and distribute customer data obtained from company's Website. Thereby, businesses obtain useful information about customer behavior. eCRM supports business serve customer better by holding valued customers and enhance ability to analyze customers. 
Business strategy toward customers is becoming the most important strategy of the Banks. Banks always have the strategy to build customer relationships and increase customers' satisfaction. The electronic banking products and services such as InternetBanking, ATM, SMS Banking, PhoneBanking, Homebanking have been implemented for a long time in the world and began offering by most of the commercial banks (CBs) in Vietnam to satisfy maximum customer needs. Banks begin to be interested in eCRM solution. However, the fact show that the implementation of eCRM solutions at banks still face many difficulties. The rate of banks fail in implementing eCRM solutions fail or can not achieve the desired efficiency is relatively high. According to Gartner's annual report, in the world, almost $70 \%$ of CRM / eCRM projects are fail. eCRM solutions at commercial banks is the information management systems solution which is large, complex, costly and risky. ECRM solutions at commercial banks is the information management systems solution which is large, complex, costly and risky. The process for implementing eCRM solutions in commercial banks is complex, taking long time, involving all parts of the bank, so it's necessary to have independent research in order to understand, analyze and evaluate objectively the implementation process, the factors affecting the success of implementing eCRM solutions. In over the world, plenty of researches on the successful implementation process, factors affecting the successful implementation of CRM / eCRM for banks in a certain scope of context. To some extent, the results of researches can be applied to the process of implementing eCRM solutions for commercial banks in Vietnam, but it must regard to the specific elements of Vietnam in law, culture, society, economy and technological infrastructure, etc ... Meanwhile, according to the understanding of the author, most domestic studies are only summarize the role and benefits of eCRM for banks, or experience in eCRM implementation in some already deployed banks. This shows that Vietnam should study to determine the factors and the impact of these factors to success of implementing eCRM solution in Vietnam's commercial banks.

The study is carried out to find models showing the relationship between factors affecting successful implementation of eCRM solution in Vietnam's commercial banks and the impact of successful implementation of eCRM solutions to customer relationships, thereby making the solution to help Vietnam's commercial banks in the process of implementing eCRM solutions. To accomplish this objective, research carries out specific following objectives:

- Identify and analyze the influence of the factors affecting the successful implementation of eCRM solution in Vietnam's commercial banks;

- Analyze the influence of successful implementation of eCRM solutions on customer relationships in Vietnam's commercial banks;

- Propose some recommendations and solutions that help banks implement successfully eCRM solutions.

\section{Theoretical Background}

\subsection{The Work System Framework}

From the socio-economic point of view and having implication that a system can combines both technical issues and problems related to human and interests of human and this system can be covered by others larger systems, Alter (2002) in his study defined "Work system" is "a system in which the participants and machinery do the work by using information, technology and other resources to create products or services to the users in and outside the system". Method of operating systems use the concept "work system" as a focus in understanding, analyzing or improving the system of institutions whether this system are related to IT or not. This method uses both static and dynamic views on the operation of the system. Static view based on "work system frame" help defines the basic elements to understand and evaluate the operating system. This framework is fully useful rules in describing the studying system, identifying challenges and opportunities, describing the possible changes, determining the influences of different parts of the system on the others. With this dynamic views, this method based on "model of work system's life cycle" to show that an operating system can be develop through several iterations of the four system's development stages, they are analysis, design, implementation and operation.

The work system has 9 components closely relating with others: 


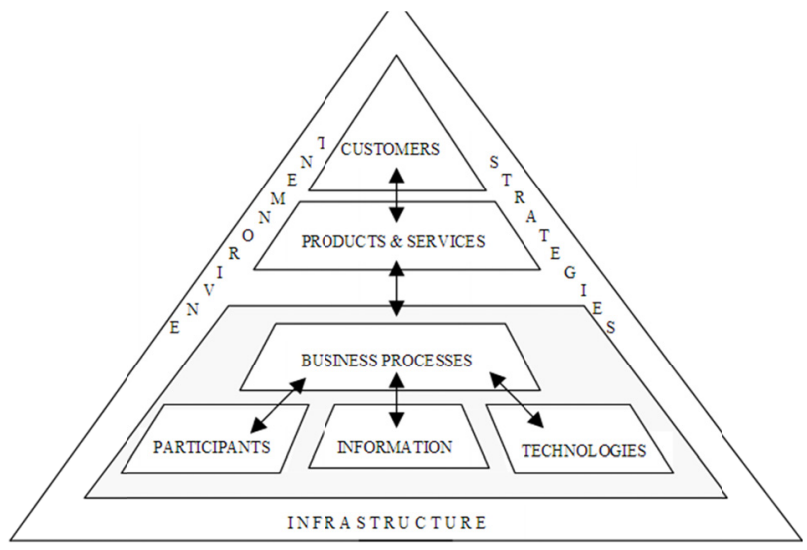

Figure 1. The work system framework

Source: Alter (2002)

eCRM system in the commercial banks is a system operating in complex environments, so operating model help researchers identify the components of system and the relationships between components in a full and multidimensional manner since the formation, implementation and operation. Using operating system model help categorize the types of risks affecting the success of eCRM, thereby identifying the factors that affect the success of eCRM implementation in Vietnam's commercial banks.

\subsection{The IS-Impact Measurement Model}

Gable et al. (2003) studied and launched model measuring the success of business information system, which consists of 4 elements: Individual Impact, Organization Impact, Information Quality and System Quality.

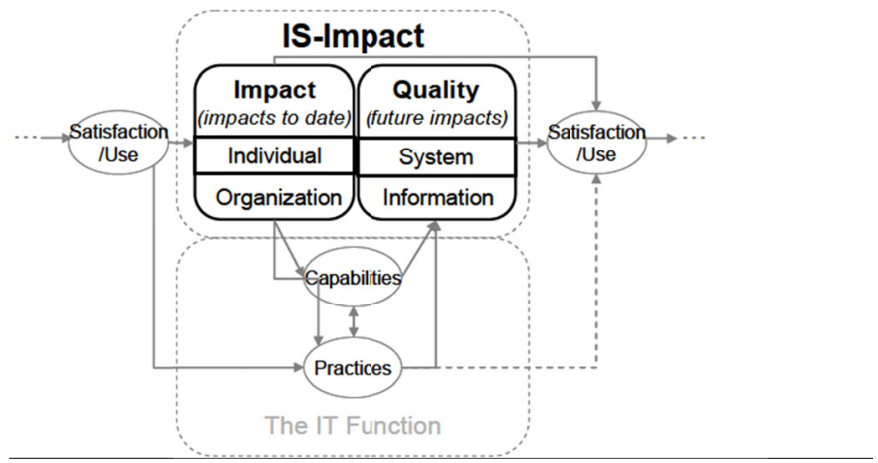

Figure 2. The IS-Impact measurement model

Source: (Gable et al., 2008)

Model measuring the impact of information systems (IS) propose represents for the pure benefit flows from the information system prior to the time of measuring and predicting in the future, as felt by all users in main using groups. Measurement model is built simple, effective, it can evaluate the whole system with a diverse context, and from perspective of the users. The model includes 4 aspects and divided into two parts. Part 'Impact' measure the benefits, demonstrated by the individuals and organizations impact; part 'quality' use Quality System and Information Quality as representative of the impacts that may occur in the future. The results of research prove necessary, additive and completeness of these four aspects.

Model measuring the impact used by information system evaluates simply in practice. The model with the aspects and measurements is designed to be simple, easy to implement and cost savings to perform evaluation on the users' views, compare in different contexts and systems. With the results measuring impact of information system of this model, the administrators easily come up with the assessment of information system of institution by comparing the 
quality and impact. When Low quality / low impact, it indicates the threat of information system, and perhaps reconsider the system. Low impact / high quality show potential for significant benefits, and need to maintain the benefits achieved from the quality. High impact / low quality: must have short-term strategies to invest improving the system quality to achieve higher profits in the future; high quality / high impact is the ultimate goal of administrators for information system.

\section{Research Models, Methods and Scope}

\subsection{Research Model and Hypotheses}

Based on the theoretical background of Alter' s model on operating system applying into the process of development, implementation and operation of eCRM system in Vietnam's commercial banks, researchers have identified 10 factors that affect the successful implementation of eCRM solutions. Research model is described in Figure 3.

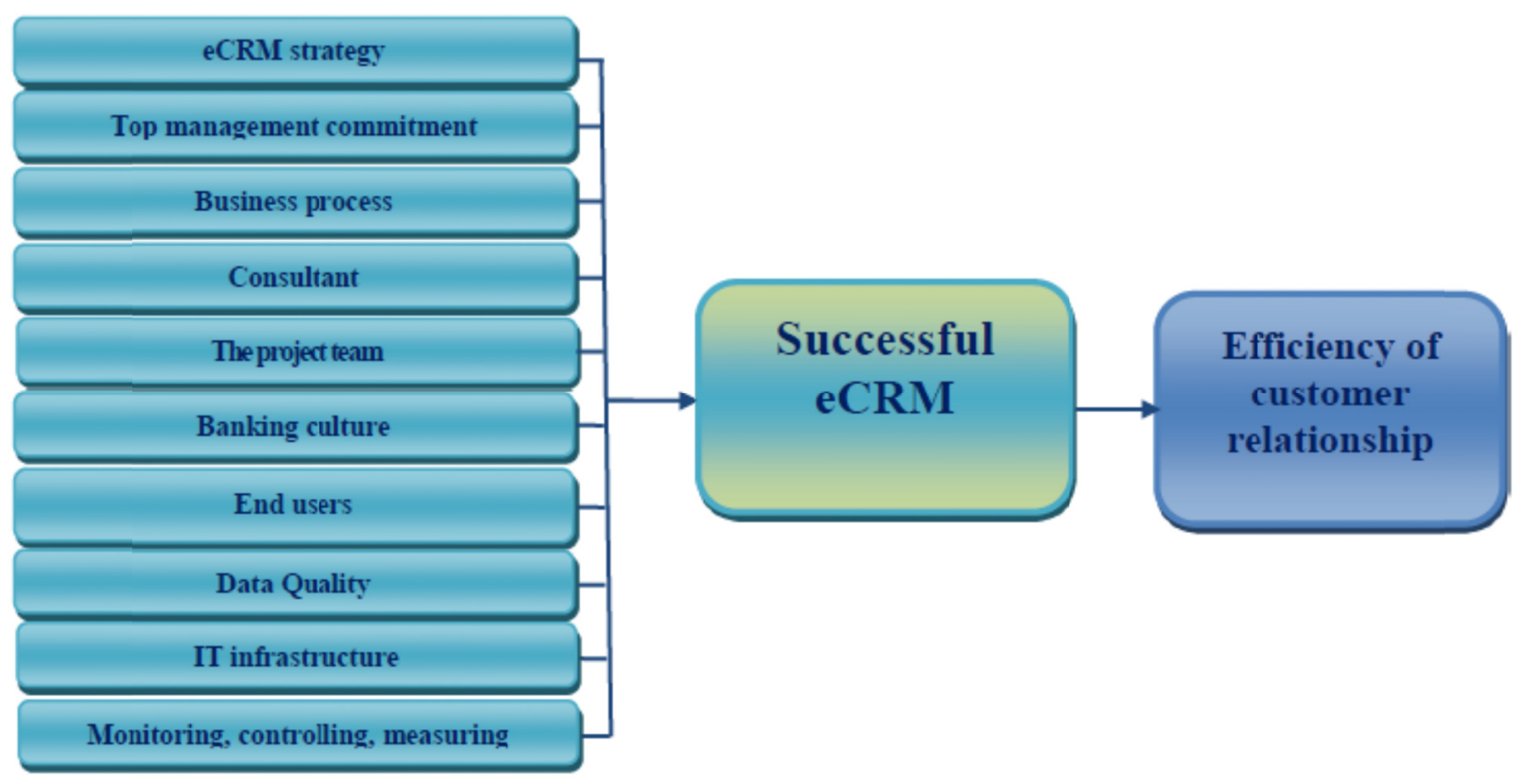

Figure 3. Research Model

eCRM strategy is consistent with the development strategy of the banks, based on the mission and core values of banks. Strategy is built with orientation regard customer as center, define clear and specific goals for each stage. ECRM strategy aim to approaching customers using modern banking products and services, help banks proactively detect, orient target customers, establish and develop sustainable relationship with customers, achieving customer satisfaction. eCRM strategy is widespread to all parts of the bank. eCRM strategy is the direction to implement successfully and operate effectively eCRM. This result is shown in the study published by Gartner (2001), Kim et al. (2002), Eid (2007), Arab et al. (2010), Esmaeilpour and Dashti (2013). In theory, the operating system, eCRM strategy affect all development stages,

\section{$\mathbf{H}_{1}$ : eCRM strategy has a positive impact on success of eCRM}

Vision, determination, a willingness of senior management of the bank to provide adequate and necessary resources in the process of implementing and operating eCRM affect directly success of eCRM . Commitment of leadership about innovation in eCRM management and implementation procedure in the process of implementing and operating the system; commit to solve disagreements among departments, coordinate activities of parts in the bank; promptly settle for bad reactions from eCRM user, which will ensure successful implementation of eCRM while operate eCRM effectively, achieving objectives of strategy. The research of Gartner (2001), Kim et al. (2002), Eid (2007) affirmed that commitment of senior leaders has great influence on implementing and operating successfully CRM / eCRM. Therefore, in this study, authors propose the following hypothesis:

$\mathbf{H}_{2}$ : Top management commitment has positive effect on success of eCRM 
Customer relationship management (CRM) is a business model which regard customers as center and is built on basis of customers. Enterprises must constantly change in the design of business process to meet the continually changing needs of customers based on behavioral information and feedback of customers. The research of Garrido-Moreno and Padilla-Meléndez (2011), Esmaeilpour and Dashti (2013) also confirmed that business procedure affect the successful implementation of CRM / eCRM. Therefore this research proposed hypothesis:

\section{$\mathbf{H}_{3}$ : Business process has proportional impact on success of eCRM}

Consultant team must have knowledge and experience in implementing eCRM solutions for banks, simultaneously understanding clearly the bank with the developing goals and strategies, actual state of customer relationship management. Skills, qualifications and experience of the consultant team has great impact on the success of eCRM solutions, because this team will give a solution, or persuade banks to use the solution, and direct bank's staff perform solutions in the business procedure of the bank. The research of Kim et al. (2002), Luis E. Mendoza et al. (2007) affirmed the influence of consultant team on success of eCRM solution. Therefore this research proposed hypothesis:

$\mathbf{H}_{4}$ : Competencies, skills and experiences of consultant team have a positive effect on the success of eCRM

The project team is the team representing for the bank combining with the consulting team to implement eCRM solution. The competencies, skills, professional levels, ability to cooperate with the consultant team of Bank's project team will affect success of eCRM. This team play the role giving the description of the operation of the business processes related to customer relationship management business along with the requirements of management, information, control, and information processing; therefore, if the capacity of this team does not guarantee, it will affect greatly success ability of eCRM. Some researches of Payne and FrowAlmotairi (2006), (2008), Abd El Kader (2012), Esmaeilpour and Dashti (2013) confirmed that skills, experiences of project team will affect the success of eCRM project. In this research author proposes hypothesis as follows:

\section{$\mathbf{H}_{5}$ : Competencies, skills and experience of project team have a positive impact on the success of eCRM}

The cultural environment in the Bank have great influence on the general success of the Bank's development as well as success in implementing any solution by the collaboration, sharing, consensus in implementation because the general goal of Bank is the basic foundation for success. Organizational culture factors are confirmed to have influence on success of eCRM in researches of Payne and Frow (2006), Sivaraks and Associates (2010), Garrido-Moreno and Padilla-Meléndez (2011), Abd El Kader (2012), Esmaeilpour and Dashti (2013). Therefore, in this research, the author proposes that culture factors in Bank affect success of e CRM and have hypothesis as follows:

\section{$\mathbf{H}_{6}:$ The banking culture has positive impact on the success of eCRM}

Skills, understanding of roles and responsibilities of each position, compliance with process and regulations when using eCRM system will affect the quality of system. Payne and Frow (2006) has emphasized that the cooperation of employees and resources management is one of the four important components in CRM implementation process of an organization. The satisfaction of using the use of customer relation skills along with the support of the CRM system will help organization implement CRM successfully (Esmaeilpour and Dashti, 2013). Therefore this research proposes hypothesis:

\section{$\mathbf{H}_{7}$ : Skill, understanding, compliance of users have proportional impact on success of eCRM}

The input data are complete, accurate, consistent, timely to ensure system provide valuable information; therefore, quality of input data affect greatly the success of eCRM. The quality of data collected and stored are evaluated through the correctness, full and timely, safety in storage and processing. Researches of (King and Burgess, 2008), (Roh et al., 2005), (Almotairi, 2010) confirmed the role of data quality with the success of eCRM. Therefore this research proposes hypothesis:

\section{$\mathbf{H}_{8}$ : Data quality has positive impact on success of eCRM}

Resources of technological infrastructure, systems, communications network related to the operation of eCRM will directly affect the operation of system, whether it ensures stable, timely or not. This is also an important factor affecting the success of eCRM. Researches of (Da Silva and Rahimi, 2007), (Alt and Puschmann, 2004), (Almotairi, 2010) affirmed the influence of technological infrastructure on success of CRM/eCRM. In this study the author proposes hypothesis as follows:

$\mathbf{H}_{\mathbf{9}}$ : Technological infrastructure has a positive impact on success of eCRM 
During the implementation process, operation of policy system, surveillance and measurement is a feedback channel evaluating system, thereby having improvements, timely adjustment so that system operate properly, achieving the set-up objectives. This is also a major factor affecting the success of CRM/eCRM implementation, whic was confirmed in the reseaches of (Da Silva and Rahimi, 2007), (Eid, 2007; Pan and Associates, 2007), (Almotairi, 2010). Therefore, in this study, authors propose the following hypothesis:

$\mathbf{H}_{\mathbf{1 0}}$ : Monitoring, controlling, measuring in the process of implementation and operation have positive impact on success of eCRM

Efficiency of customer relationships are often evaluated through customers' satisfaction, trust, loyalty, commitment, willingness to introduce others people to use products and services of the Bank. Sivaraks et al. (2011), Maroofi (2012) demonstrated by experiment in the banking industry in Thailand and Iran the relationship between successful eCRM deployment and efficiency of customer relationships. Therefore this research proposes hypothesis:

$\mathbf{H}_{11}$ : The success of eCRM has a proportional impact on the to efficiency of customer relationship

\subsection{Research Methods}

Research process follows these steps:

- Overview of research: Based on the theories of Alter's operating system to determine the research model, hypothesis and measurement scale. The scales in English was translated into Vietnamese and adjusted words by consulting the experts, then translate conversely to evaluate homogeneity of the meaning of the questions in the translation process. The measurement scale and references are shown in Appendix 1.

- Qualitative research: Make 5 in-depth interviews with leader, head of the project, the consultants of eCRM solution in Vietnam's commercial banks. Qualitative research helps the author check the research model, adjust measurement scale and calibrate suitable research models.

-Preliminary quantitative research: Research conducted the trial investigation with 50 employees, leaders of the Bank that has engaged to implement and operate eCRM solutions directly and online. The result of this step help research check and calibrate the measurement scale.

- Official quantitative research: Design the written questionnaires and online questionnaires, then send written and online questionnaires to the survey entity, collect data, process and analyze collected data.

\subsection{Research Form}

According to the Hair et al. (1998), the sample size in official quantitative research, for analysis of factors exploring EFA, the minimum sample size is larger five times than the total indicators of measurement scale. This study has 61 indicators using factor analysis, therefore the minimum sample size is $61 * 5=305$ observations. According to Tabachnick et al. (2001), this study has 10 independent variable, so the minimum sample size is $50+8 * 10=130$ observations. Combining 2 above requirements, the minimum sample size for this study was 305 observations. Research taken votes directly and online. The object of the investigation is the management team, employees of the bank related to implementation and operation of eCRM system in 10 Vietnam's commercial banks which have been implementing the eCRM/CRM solution, consultant team of eCRM solutions for commercial banks in Vietnam. Obtaining vote directly and onlines must ensure a wide spectrum of gender, age, seniority, expertise, field, position. Time to complete the votes collection is 3 months $(01 / 2016-03 / 2016)$. The number of votes taken back is 352 , in which there are 302 direct votes (ratio 302/500 reaching 60\%), 50 online votes (ratio 50/600 online reaching 8.3\%). The study had to junk 44 votes because of lacking many important information or the study consider that answer in these votes are non-cooperation. The number of votes obtained from 10 commercial banks which is valid and put into the data analysis is 308 votes.

\subsection{Data Analysis Method}

After having the data, using economics tools to analyze and evaluate relationships in research model: Evaluate the reliability of measurement scale using Cronbach Alpha reliability coefficients, EFA, CFA, SEM.

\section{Research Results}

\subsection{Reliability of Measurement Scales}

To assess the suitability of variable when put into the model, the study checks the reliability of the measurement scale using Cronbach Alpha reliability coefficients. Test results showed that Cronbach Alpha coefficient of business process factors $(\alpha=0.455)$, eCRM system users $(\alpha=0.394)$, Testing, monitoring and measurement $(\alpha=0.419)$ are smaller than 0.6 , therefore variables in 3 measurement scale is eliminated. 
In addition, some observations variables having general correlation coefficient $<0.3$ also eliminated, including: $\mathrm{CK}_{4}$, $\mathrm{CK}_{5}, \mathrm{CL}_{5}, \mathrm{DA}_{5}, \mathrm{DL}_{4}, \mathrm{VH}_{3}, \mathrm{VH}_{5}, \mathrm{HT}_{5}, \mathrm{TC}_{5}, \mathrm{HQ}_{6}$. Detailed results assessing measurement scale by Cronbach Alpha reliability for the first $\left(1^{\text {th }}\right)$ time is shown in the table.

Checking the reliability of the measurement scale using Cronbach Alpha reliability coefficients in the second $\left(2^{\text {th }}\right)$ times, all the observation variables having correlatton with the general variables are greater than 0.3 and Cronbach Alpha coefficient of the factors are greater than 0.6 , so measurement scale of components $\mathrm{CL}\left(\mathrm{CL}_{1}, \mathrm{CL}_{2}, \mathrm{CL}_{3}, \mathrm{CL}_{4}\right)$; $\mathrm{CK}\left(\mathrm{CK}_{1}, \mathrm{CK}_{2}, \mathrm{CK}_{3}\right)$; TV $\left(\mathrm{TV}_{1}, \mathrm{TV}_{2}, \mathrm{TV}_{3}, \mathrm{TV}_{4}, \mathrm{TV}_{5}\right)$; $\mathrm{DA}\left(\mathrm{DA}_{1}, \mathrm{DA}_{2}, \mathrm{DA}_{3}, \mathrm{DA}_{4}\right) ; \mathrm{DL}\left(\mathrm{DL}_{1}, \mathrm{DL}_{2}, \mathrm{DL}_{3}, \mathrm{DL}_{5}\right)$; VH $\left(\mathrm{VH}_{1}, \mathrm{VH}_{2}, \mathrm{VH}_{4}\right)$; HT $\left(\mathrm{HT}_{1}, \mathrm{HT}_{2}, \mathrm{HT}_{4}, \mathrm{HT}_{3}\right)$; $\mathrm{TC}\left(\mathrm{TC}_{1}, \mathrm{TC}_{2}, \mathrm{TC}_{3}, \mathrm{TC}_{4}\right)$; HQ $\left(\mathrm{HQ}_{1}, \mathrm{HQ}_{2}, \mathrm{HQ}_{3}, \mathrm{HQ}_{4}, \mathrm{HQ}_{5}\right)$ were accepted and put into the next factor analysis. Detailed results assessing measurement scale by Cronbach Alpha reliability for the $2^{\text {th }}$ time is shown in Table 1.

Table 1. Results assessing measurement scale by Cronbach Alpha reliability

\begin{tabular}{|c|c|c|c|}
\hline Factor & $\begin{array}{c}\text { The } \\
\text { observation } \\
\text { variable }\end{array}$ & $\begin{array}{c}\text { General variable } \\
\text { correlation coefficient }\end{array}$ & $\begin{array}{c}\text { Alpha if eliminating } \\
\text { variable }\end{array}$ \\
\hline \multirow{4}{*}{$\begin{array}{c}\text { eCRM strategies } \\
\text { of Bank } \alpha= \\
0.827\end{array}$} & $\mathrm{CL}_{1}$ & ,742 & ,740 \\
\hline & $\mathrm{CL}_{2}$ &, 487 &, 850 \\
\hline & $\mathrm{CL}_{3}$ & 675 &, 773 \\
\hline & $\mathrm{CL}_{4}$ &, 721 &, 750 \\
\hline \multirow{3}{*}{$\begin{array}{c}\text { Top management } \\
\text { commitment } \alpha= \\
0.883 \\
\end{array}$} & $\mathrm{CK}_{1}$ & ,799 &, 809 \\
\hline & $\mathrm{CK}_{2}$ &, 724 &, 881 \\
\hline & $\mathrm{CK}_{3}$ &, 817 & ,797 \\
\hline \multirow{5}{*}{$\begin{array}{c}\text { Consultants team } \\
\alpha=0,810\end{array}$} & $\mathrm{TV}_{1}$ & ,627 &, 764 \\
\hline & $\mathrm{TV}_{2}$ &, 725 &, 732 \\
\hline & $\mathrm{TV}_{3}$ & ,648 &, 759 \\
\hline & $\mathrm{TV}_{4}$ &, 328 &, 852 \\
\hline & $\mathrm{TV}_{5}$ & ,694 &, 741 \\
\hline \multirow{4}{*}{$\begin{array}{c}\text { The } \\
\text { eCRMproject } \\
\text { team of bank } \alpha= \\
0.751\end{array}$} & $\mathrm{DA}_{1}$ & 706 &, 595 \\
\hline & $\mathrm{DA}_{2}$ & ,418 &, 759 \\
\hline & $\mathrm{DA}_{3}$ &, 527 & ,704 \\
\hline & $\mathrm{DA}_{4}$ &, 548 & ,693 \\
\hline \multirow{3}{*}{$\begin{array}{c}\text { Banking culture } \\
\alpha=0,853\end{array}$} & $\mathrm{VH}_{1}$ & ,764 & ,757 \\
\hline & $\mathrm{VH}_{2}$ & ,678 & ,838 \\
\hline & $\mathrm{VH}_{4}$ &, 736 &, 785 \\
\hline \multirow{4}{*}{$\begin{array}{l}\text { data quality of } \\
\text { eCRM systems } \alpha \\
=0.718\end{array}$} & $\mathrm{DL}_{1}$ &, 562 & ,622 \\
\hline & $\mathrm{DL}_{2}$ &, 580 & ,610 \\
\hline & $\mathrm{DL}_{3}$ & ,557 & ,625 \\
\hline & $\mathrm{DL}_{5}$ &, 336 & ,749 \\
\hline \multirow{4}{*}{$\begin{array}{c}\text { Technological } \\
\text { infrastructure } \\
\alpha=0,900\end{array}$} & $\mathrm{HT}_{1}$ &, 840 &, 846 \\
\hline & $\mathrm{HT}_{2}$ &, 712 &, 893 \\
\hline & $\mathrm{HT}_{3}$ &, 722 & ,889 \\
\hline & $\mathrm{HT}_{4}$ & ,837 & 847 \\
\hline \multirow{4}{*}{$\begin{array}{l}\text { Successful } \\
\text { eCRMsolution } \alpha \\
=0.840\end{array}$} & $\mathrm{TC}_{1}$ & ,712 & ,781 \\
\hline & $\mathrm{TC}_{2}$ &, 754 &, 762 \\
\hline & $\mathrm{TC}_{3}$ & ,617 &, 822 \\
\hline & $\mathrm{TC}_{4}$ &, 623 &, 821 \\
\hline \multirow{5}{*}{$\begin{array}{c}\text { Efficiency of } \\
\text { customer } \\
\text { relations } \alpha= \\
0.824\end{array}$} & $\mathrm{HQ}_{1}$ &, 743 & ,749 \\
\hline & $\mathrm{HQ}_{2}$ & ,612 & ,790 \\
\hline & $\mathrm{HQ}_{3}$ & ,611 &, 791 \\
\hline & $\mathrm{HQ}_{4}$ &, 562 &, 804 \\
\hline & HQ5 &, 563 & ,804 \\
\hline
\end{tabular}




\subsection{Exploratory Factor Analysis EFA}

The factors affecting success of eCRM system (TC) is measured by 50 observation variables. After evaluating the measurement scale by Cronbach Alpha, there are 27 variables ensure reliability. Exploratory Factor analysis EFA is used to reassess the extent of convergence of the observation variables by the components. The study check KMO and Bartlett's in factor analysis showed high KMO coefficient $(=0.794>0.5)$ Bartlett's testing values have meaning (Sig. $=0.000<0.05)$ shows that EFA factors are suitable. At the Eigenvalues greater than 1 and factor extracted used is Principal Axis Factoring (PAF) and non-perpendicular rotations Promax, analyzing extracted factor are 7 factors from 27 observation variable with variance extracted is 57,435\% (greater than 50\%) meet requirement. Perform analysis EFA times 1, eliminating 2 observation variables TV4, DL5 because load factor $<0.4$. Then study perform EFA in $2^{\text {th }}$ time, results is shown in the following table:

Table 2. Results of explore factor analysis EFA

\begin{tabular}{rr}
\hline \multicolumn{2}{c}{ KMO and Bartlett's Test } \\
\hline Kaiser-Meyer-Olkin Measure of Sampling Adenuacy. &, 792 \\
\hline Approx Chi-Square & 3663.187 \\
\hline Sig. &, 000 \\
\hline
\end{tabular}



Results of EFA (table 2) with KMO $=0.792$, Bartlett test value have meaning ( $\operatorname{sig}<0.05$ ), 7 groups of factors are quoted with the total variance extracted is $60.837 \%$. 


\subsection{Confirmatory Factor Analysis (CFA) and Structural Equation Model (SEM)}

Based on the result of EFA: 7 factors (25 observed variables) affecting successful eCRM solution (4 observed variables), successful eCRM impacts on customer relationship (5 observed variables), study Confirmatory factor analysis (CFA) the first time by AMOS 20 software. Result of the 1st CFA has DA2 observed variables, weight of 0.473 is smaller than the allowed standard $(>=0.5)$ so that scale achieves convergence value (Gerbing \& Anderson, 1988), so this variable will be disqualified and conduct CFA the second time Result of CFA is shown in the following figure:

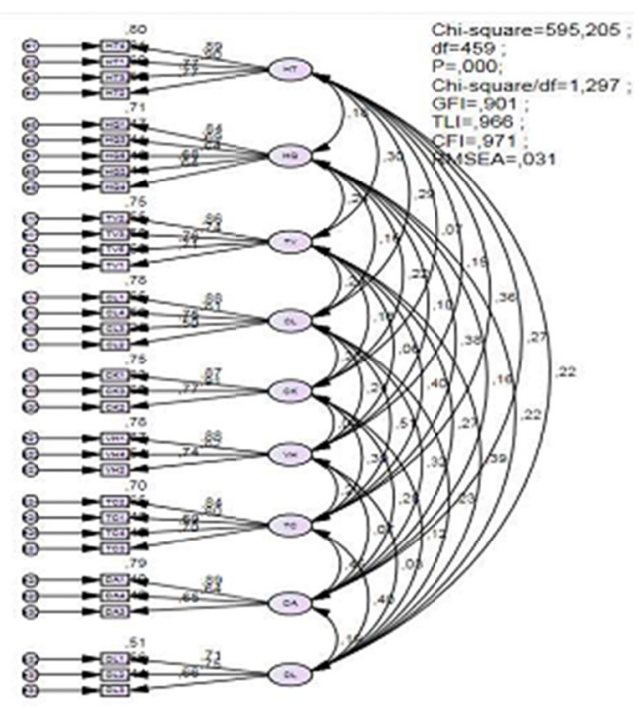

Figure 4. CFA Model

Table 3. Synthetic reliability and extracted variance

\begin{tabular}{lccc}
\hline & Factor & CR & AVE \\
\hline DL & Data Quality & 0,855 & 0,664 \\
\hline VH & Banking culture & 0,832 & 0,563 \\
\hline HQ & $\begin{array}{c}\text { Effectiveness of customer } \\
\text { relationship }\end{array}$ & 0,827 & 0,491 \\
\hline CL & eCRM Strategy & 0,855 & 0,596 \\
\hline HT & IT infrastructure & 0,902 & 0,698 \\
\hline TV & Deploying consultants & 0,887 & 0,725 \\
\hline TC & successful eCRM & 0,845 & 0,578 \\
\hline CK & Commitment of senior leaders & 0,750 & 0,501 \\
\hline
\end{tabular}

Result of the second CFA, observed weighting variables meet standard $(>=0.5)$ and has statistics meaning p values are by 0.000 (the lowest weighting variables CL2 $=0.504$ ). Thus it can be concluded the observed variables used to measure the component variable of scale achieve convergence value. The second CFA shows model has 459 free degrees, test value Chi -square $=595.205$, with $\mathrm{p}$-value $=0.000<0.05$; Chi-square $/ \mathrm{df}=1,297$ satisfactory $<2$ and the index indicates the model fit the market data $(\mathrm{CFI}=0.971$; TLI $=0.966$; GFI $=9.01>0.9$ and RMSEA $=0.069<$ 0.08). The components of ECRM strategy, commitment of senior leaders, implementing consultants, eCRM project team of the bank, banking culture, data quality, IT infrastructure of the bank have no correlation between the error of observed variables so they achieve unidirectional quality Also examining distinguishing values of the concepts in the model. The result shows that the concepts in the model achieve differentiated value.

Structural equation model with AMOS 20 software obtain as follows: 


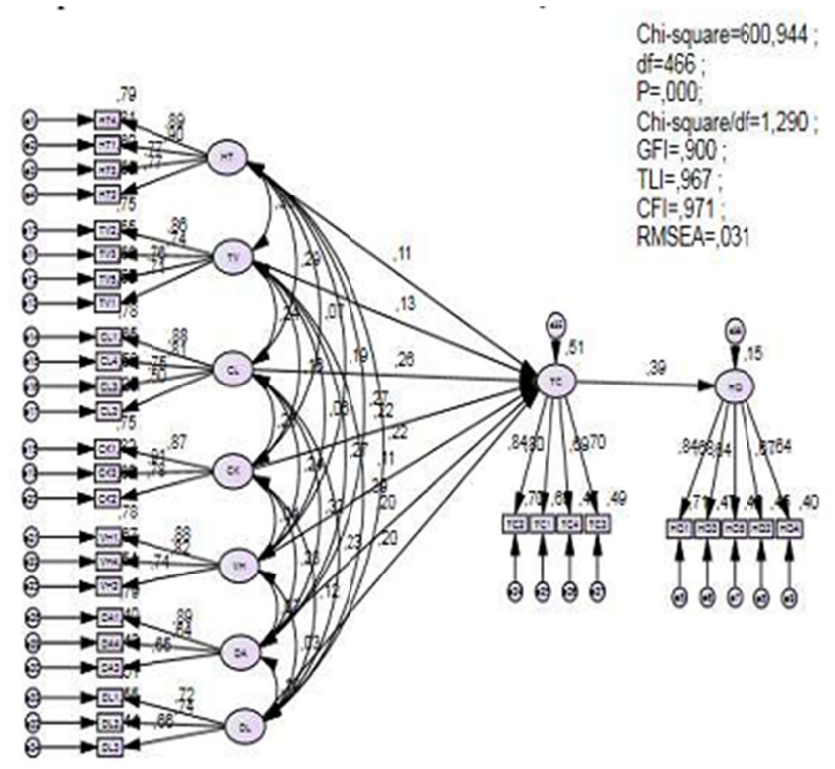

Figure 5. Structural equation model of research

Table 4. The weights are not standardized SEM

\begin{tabular}{cccccccc}
\hline & & & $\begin{array}{c}\text { Estimat } \\
\mathbf{e}\end{array}$ & S.E. & CR & P & Label \\
\hline TC & $<---$ & HT &, 085 &, 042 & 2.017 &, 044 & \\
\hline TC & $<---$ & TV &, 127 &, 057 & 2.213 &, 027 & \\
\hline TC & $<---$ & CL &, 209 &, 050 & 4.212 & $* * *$ & \\
\hline TC & $<---$ & CK &, 164 &, 041 & 3.997 & $* * *$ & \\
\hline TC & $<---$ & VH &, 071 &, 035 & 2.025 &, 043 & \\
\hline TC & $<---$ & DA &, 170 &, 053 & 3.206 &, 001 & \\
\hline TC & $<---$ & DL &, 215 &, 068 & 3.168 &, 002 & \\
\hline
\end{tabular}

Table 5. The standardized weights SEM

\begin{tabular}{cccc}
\hline & & & Estimate \\
\hline TC & $<---$ & CL & 0.256 \\
\hline TC & $<---$ & CK & 0.219 \\
\hline TC & $<---$ & DL & 0.204 \\
\hline TC & $<---$ & DA & 0.197 \\
\hline TC & $<---$ & TV & 0.135 \\
\hline TC & $<---$ & HT & 0.113 \\
\hline TC & $<---$ & VH & 0.109 \\
\hline HQ & $<---$ & $\begin{array}{c}\text { Cred } \\
\text { it }\end{array}$ & 0.391 \\
\hline
\end{tabular}

Table 6. Squared Multiple Correlations

\begin{tabular}{ll}
\hline & Estimate \\
\hline $\mathrm{TC}$ &, 510 \\
\hline $\mathrm{HQ}$ &, 153 \\
\hline
\end{tabular}




\subsection{Results of Hypothesis Testing}

Based on the research result with survey data, the study points out the hypotheses $\mathrm{H}_{3}, \mathrm{H}_{7}, \mathrm{H}_{10}$ are unacceptable and hypotheses $\mathrm{H}_{1}, \mathrm{H}_{2}, \mathrm{H}_{4}, \mathrm{H}_{5}, \mathrm{H}_{6}, \mathrm{H}_{8}, \mathrm{H}_{9}, \mathrm{H}_{11}$ are accepted.

\section{Conclusion and Recommendation}

\subsection{Discuss the Research Result}

Research model is built based on the model of work system of Alter (2002) proposed to study in organizational systems based on both static and dynamic views to assess the systems. Based on the theoretical model of electronic customer in the commercial banks. In addition the study also inherits the previous research results published proposal of testing the effects of successful eCRM implementation to effectiveness of customer relationship at the Vietnam commercial banks.

With quantitative research method, analytical method used to discover EFA factor, confirmed factor analysis CFA, structural equation model SEM, research result shows that the factors affect successful eCRM implementation in commercial banks including eCRM strategy, Top management commitment, IT infrastructure, consulting team to implement the project, the project team eCRM,banking culture, data quality according to the hypothesis posed. The result of analysis of research data also shows successful eCRM implementation will impact on effectiveness of customer relationship at commercial banks. As follows:

First, the research result confirms the management strategy of electronic customer relationship, group of human factor (Top management commitment, implementation consultants, project team of the bank), group of technology element (technology infrastructure, data quality) strongly influence on successful eCRM deployment at commercial banks. This is consistent with the announced research results.

Second, the research result confirms banking cultural factor affects successful eCRM implementation at commercial banks in line with the context of the commercial banks in Vietnam, a collective culture. Collaboration, sharing in banking environment will greatly affect the task implementation in general and eCRM deployment in particular.

Third, the research result indicates the affecting order of the factors to successful eCRM implementation is: eCRM strategy, Top management commitment, data, eCRM project team of banks, consultants, technology infrastructure, banking culture, in which eCRM strategy has the most powerful influence. These factors explain $51 \%$ of variance of eCRM solution success.

Fourth, the research result also confirms successful eCRM implementation affects effectivenss of customer relationship at commercial banks. The concept of success of eCRM explains $15.3 \%$ of variance of effectiveness of customer relationship at commercial banks.

Fifth, the scales for the factors affecting success of eCRM solutions, assessment of eCRM success, effectiveness of customer relationship achieve unidirectional, convergence, reliability and highly distinguishing value shown through CFA analysis data and structural equation model.

Finally, the research result offers a suitable model for market data with standard statistical indicators: Chisquare=1,290 $(<2)$; TLI=0,967; CFI=0,971; GFI=0,900 (>0,9); RMSEA=0,031 $(<0,08)$. Bootstrap accreditation confirms estimated SEM model can be trusted.

\subsection{Some Proposals}

Based on the research result on the factors affecting successful eCRM implementation, author proposes some suggestions for Vietnam commercial banks in the process of implementing eCRM solution, as follows:

\section{eCRM strategy}

eCRM strategy formulation is the first step in the process of implementing CRM for a bank. Banks should build a strategy of electronic customer relationship management, customer-centric in which that needs of customer directs for all operations of the bank. Full eCRM strategy with clear objectives based on the general strategic development of the bank will support maximum the eCRM implementation process. About eCRM strategy communication to all parts of the bank will help the entire bank staff aware of the meaning and objectives and benefit of eCRM for bank thereby facilitating maximum successful eCRM implementation.

\section{Commitment of senior leaders}

The determination of interest, the maximum commitment to support the implementation process of the senior leader of bank is the factor guaranteeing success for implementing eCRM at bank. During the implementation process will 
face many problems arising beyond the control of the project team, so need settlement of senior leaders. The drastic, thorough direction and timely support of senior leaders during project implementation period at the same time has timely decisions to ensure the implementing progress as well as quality of the project, to ensure success, achieving its objectives.

\section{The human factor in implementing eCRM}

The human factor plays an important role in the successful deployment of management information system solution in general and eCRM solution for commercial banks in particular. The projects of successful information system implementation in general has pointed out the human factor accounts for $60 \%$ of success, process accounts for $30 \%$ and $10 \%$ is dependent on technological factor. Human factor in the process of implementing eCRM at a fairly wide bank in which to focus on some key elements are: Qualification and experience of consultants, solution deployment; Qualification and experience of the project team of the bank.

On the consultants implementing eCRM solution: In the process of implementing eCRM solution, the role of the implementing consultants is very important because this is a team of analysts, designers, offer appropriate solutions and implement that solution to customer relationship management of the bank. Thus, the bank really needs a team of consultants has sufficient knowledge and experience in implementing eCRM for commercial banks. This is a big challenge for commercial banks when selecting this team because in Vietnam this team is really not much, not much experience in the deployment while international consulting team is not deep. The criteria for evaluating implementing consultants the banks need to assess based on: experience in consulting, deployment; scale of implementing and consulting banks; the stability of long-term commitment; deep understanding of the operation of commercial banks in Vietnam and the business characteristics of implementing banks; acknowledge of customer culture, grasp well customer trends in the products of modern banking services; good knowledge of banking technology. Implementing consultants need to separate into two separate groups including Implementation and Consultant to ensure objectivity.

The project team of the bank: Banks should establish eCRM project management unit with the full participation of the relevant specialized department to coordinate in building strategy and specific development plan, deployment of eCRM solution. eCRM project team need good profession on customer relationship management, knowledge of banking products and services, customer knowledge, changing trend of the needs and behavior of customers for banking services, the ability to analyze and describe, assess the involved business processes. The project team identifies fully the requirements of bank management, requests detailed information and gathers and then transmit the requirements to a team of implementing consultants to include in the solution. Collaboration skills with implementing consultants is critical skills of the project team. On the other hand the project team needs a full understanding of test, assessment and control the management processes that are transferred into the process of eCRM solution. Also experience in implementing projects, IT application is also important for the project team. To successfully implement eCRM for commercial banks, not only the project team needs skills, ability and experience, clear project organization structure but also the banks need to learn and control project implementation according to international standards.

\section{The investment in technology application at bank}

Technology plays an important role for successful eCRM solution deployment at commercial banks reflected in two important factors are the IT infrastructure and data quality.

IT infrastructure: Along with the powerful development of the IT, the Internet and social networks and smart mobile devices makes big changes in behavior, habit and customer demand for the banking products and services, the commercial banks is required to have a modern technological infrastructure. The basic technology of eCRM system include specialized customer data warehouse (data mart); applications for data analysis; building the customer experience for banking products, personalized and consistent across all trading channels; setting the trading channel Internet Banking, Mobile Banking, social network, vv.. create condition for favorable customer interaction. The existing IT system of the bank should stable, reliable operate, easy to improve and expand, with high security, have the ability to integrate and optimized architecture will be important success background in the process of implementing eCRM.

Data quality: Input data quality will ensure eCRM system provide quality output information, to ensure the success of the system. The eCRM system data of the bank is varied from various sources such as transaction data from other systems such as Core Banking; transaction data from modern transaction banking channels such as ATM modern, Internet Banking, Mobile Banking, etc ...; Customer behavior data on the website, on social networks, etc ...; 
Customer data from customer relationship from the Call Center System, Email, etc ... All data sources are integrated to synchronize on eCRM system with complete requirement, accurate, timely updated and automatic with automatic data collection technology, store, analyze and process in real-time, high security technology.

\section{Build a culture of cooperation, sharing in bank}

Banking culture greatly affect the bank successful eCRM implementation. Banking culture should be shaped into consciousness, attitude, habit of the entire bank staff. It's a culture oriented to customer from awareness inside and action of employees then help employees realize the importance of customer and customer relationship. This will be the basic foundation to be able to successfully implement eCRM, helping eCRM system operate efficiently. On the other hand the cultural environment of cooperation, sharing in the bank will make the implementing process favorable, fast and efficient.

\section{References}

A. Garrido-Moreno, \& A. Padilla-Meléndez. (2011). Analyzing the impact of knowledge management on CRM success: The mediating effects of organizational factors. International Journal of Information Management, 31, 437-444.

A. Payne, \& P. Frow. (2006). Customer relationship management: from strategy to implementation. Journal of marketing management, 22, 135-168.

B. G. Tabachnick, L. S. Fidell, \& S. J. Osterlind. (2001). Using multivariate statistics.

F. Arab, H. Selamat, S. Ibrahim, \& M. Zamani. (2010). A survey of success factors for CRM. In Proceedings of the World Congress on Engineering and Computer Science, 20-22.

F. Maroofi, A. Darabi, \& J. Torabi. (2012). Effects of e-CRM on Customer-Bank Relationship Quality and Results. International Journal of Academic Research in Accounting, Finance and Management Sciences, 2, 164-182.

Gartner. (2001). Eight building blocks of CRM: A framework for success. Gartner research, 13, 1-4.

H.-W. Kim, G.-H. Lee, \& S. Pan. (2002). Exploring the critical success factors for customer relationship management and electronic customer relationship management systems. ICIS 2002 Proceedings, 93.

J. F. Hair, W. C. Black, B. J. Babin, R. E. Anderson, \& R. L. Tatham. (1998). Multivariate data analysis (5 ed.). Pearson Prentice Hall Upper Saddle River, NJ.

Luis E. Mendoza, Alejandro Marius, Maria Perez, \& Ann a C. Griman. (2007). Critical success factors for a customer strategy. Information Software Technology, 49, 913-945.

M. A. Almotairi. (2010). Evaluation of the Implementation of CRM in Developing Countries. Brunel University Brunel Business School PhD Theses.

M. Almotairi. (2008). CRM SUCCESS FACTORS TAXONOMY. In European and Mediterranean Conference on Information Systems, 29-35.

M. Esmaeilpour, \& F. R. Dashti. (2013). Identifying and Ranking the Factors Affecting Electronic Customer Relationship Management Infrastructure in Small and Medium Enterprises.

N. Abd El Kader. (2012). E-customer relationship management readiness in the banking industry: the case of Egypt. Middlesex University.

P. Sivaraks, D. Krairit, \& J. C. Tang. (2011). Effects of e-CRM on customer-bank relationship quality and outcomes: The case of Thailand. The Journal of High Technology Management Research, 22, 141-157.

P. Sivaraks, D. Krairit, \& V. Esichaikul. (2010). Measuring e-CRM implementation and outcomes from the customers' perspectives. In Technology Management for Global Economic Growth (PICMET), 2010 Proceedings of PICMET'10, 1-10.

R. Alt, \& T. Puschmann. (2004). Successful practices in customer relationship management. In System Sciences, 2004. Proceedings of the 37th Annual Hawaii International Conference on, 9.

R. Eid. (2007). Towards a successful CRM implementation in banks: An integrated model. The Service Industries Journal, 27, 1021-1039.

R. V. Da Silva, \& I. Rahimi. (2007). A critical success factor model for CRM implementation. International Journal of Electronic Customer Relationship Management, 1, 3-15. 
S. Alter. (2002). The work system method for understanding information systems and information systems research. Communications of the Association for Information Systems, 9, 6.

S. F. King, \& T. F. Burgess. (2008). Understanding success and failure in customer relationship management. Industrial Marketing Management, 37, 421-431.

S. L. Pan, \& J.-N. Lee. (2003). Using e-CRM for a unified view of the customer. Communications of the ACM, 46, 95-99.

T. H. Roh, C. K. Ahn, \& I. Han. (2005). The priority factor model for customer relationship management system success. Expert systems with applications, 28, 641-654.

Z. Pan, H. Ryu, \& J. Baik. (2007). A case study: CRM adoption success factor analysis and Six Sigma DMAIC application In Software Engineering Research, Management \& Applications, 2007. SERA 2007. 5th ACIS International Conference on, 828-838.

Appendix 1. The scale

\begin{tabular}{|c|c|c|c|}
\hline Variable & Encryption & Scale & $\begin{array}{l}\text { Reference } \\
\text { source }\end{array}$ \\
\hline \multirow{5}{*}{$\begin{array}{l}\text { eCRM Strategy } \\
\text { of the bank }\end{array}$} & $\mathrm{CL}_{1}$ & ECRM development strategy & \multirow{5}{*}{$\begin{array}{l}\text { Apply the } \\
\text { adjusted } \\
\text { scale } \\
\text { (Almotairi, } \\
\text { 2010), Abd } \\
\text { El Kader } \\
\text { (2012) }\end{array}$} \\
\hline & $\mathrm{CL}_{2}$ & Development strategyof electronic bank & \\
\hline & $\mathrm{CL}_{3}$ & Specific objectives of the eCRM strategy & \\
\hline & $\mathrm{CL}_{4}$ & ECRM strategy communication & \\
\hline & $\mathrm{CL}_{5}$ & OveralleCRM strategy assessment & \\
\hline \multirow{5}{*}{$\begin{array}{c}\text { Top } \\
\text { management } \\
\text { commitment }\end{array}$} & $\mathrm{CK}_{1}$ & Senior leaders are committed to innovate management process & \multirow{5}{*}{$\begin{array}{l}\text { Apply with } \\
\text { adjusted } \\
\text { scale of } \\
\text { Esmaeilpour } \\
\text { and Dashti } \\
\text { (2013) }\end{array}$} \\
\hline & $\mathrm{CK}_{2}$ & Senior leaders have eCRMknowledge & \\
\hline & $\mathrm{CK}_{3}$ & Senior leaders approve estimated funding of eCRM implementation & \\
\hline & $\mathrm{CK}_{4}$ & $\begin{array}{l}\text { Senior leaders are involved in the process ofeCRM operation and } \\
\text { implementation }\end{array}$ & \\
\hline & $\mathrm{CK}_{5}$ & $\begin{array}{l}\text { Senior leaders support handling disagreements between } \\
\text { departments, timely response to the negative reaction of the users }\end{array}$ & \\
\hline \multirow{5}{*}{$\begin{array}{l}\text { Business } \\
\text { Process }\end{array}$} & $\mathrm{QT}_{1}$ & $\begin{array}{l}\text { The business processesinvolved are designed into the processing of } \\
\text { eCRM systems }\end{array}$ & \multirow{5}{*}{$\begin{array}{l}\text { Apply with } \\
\text { adjusted } \\
\text { scale of } \\
\text { Esmaeilpour } \\
\text { and Dashti } \\
\text { (2013) }\end{array}$} \\
\hline & $\mathrm{QT}_{2}$ & The process of eCRM are documented and consistent & \\
\hline & $\mathrm{QT}_{3}$ & $\begin{array}{l}\text { The activities and tasks in the process of eCRM are assigned } \\
\text { specifically and clearly }\end{array}$ & \\
\hline & $\mathrm{QT}_{4}$ & The processes of eCRM are measured to assess the effectiveness & \\
\hline & $\mathrm{QT}_{5}$ & The processes of eCRM are simple, flexible, easy to use & \\
\hline \multirow{5}{*}{$\begin{array}{c}\text { Team of } \\
\text { implementation } \\
\text { consultants }\end{array}$} & $\mathrm{TV}_{1}$ & $\begin{array}{l}\text { Team ofeCRMimplementation consultants understands business } \\
\text { operations of banks }\end{array}$ & \multirow{5}{*}{$\begin{array}{l}\text { Applywith } \\
\text { adjusted } \\
\text { scale of } \\
\text { (Luis E. } \\
\text { Mendoza } \\
\text { and } \\
\text { coworker, } \\
\text { 2007), } \\
\text { (Esmaeilpour } \\
\text { and } \\
\text { Dashti, } \\
\text { 2013) }\end{array}$} \\
\hline & $\mathrm{TV}_{2}$ & $\begin{array}{l}\text { Team of implementation consultants has in-depth knowledge of } \\
\text { customer and e-banking services }\end{array}$ & \\
\hline & $\mathrm{TV}_{3}$ & $\begin{array}{l}\begin{array}{l}\text { Team of implementation consultants has experience in } \\
\text { implementing eCRM at banks }\end{array} \\
\end{array}$ & \\
\hline & $\mathrm{TV}_{4}$ & $\begin{array}{l}\text { Team of implementation consultants has analytical methods and } \\
\text { designs well business processes }\end{array}$ & \\
\hline & $\mathrm{TV}_{5}$ & $\begin{array}{l}\text { Team of implementation consultants supports use and eCRM good } \\
\text { warranty and maintenance }\end{array}$ & \\
\hline
\end{tabular}




\begin{tabular}{|c|c|c|c|}
\hline \multirow{5}{*}{$\begin{array}{l}\text { The eCRM } \\
\text { project team } \\
\text { of the bank }\end{array}$} & $\mathrm{DA}_{1}$ & $\begin{array}{l}\text { There is a complete representative of the functional units involved } \\
\text { in the eCRM project team }\end{array}$ & \multirow{5}{*}{$\begin{array}{c}\text { Apply with } \\
\text { the adjusted } \\
\text { scale } \\
\text { (Almotairi, } \\
\text { 2010), } \\
\text { (Esmaeilpour } \\
\text { and } \\
\text { Dashti, } \\
\text { 2013) }\end{array}$} \\
\hline & $\mathrm{DA}_{2}$ & $\begin{array}{l}\text { The project team has a high level of expertise and knowledge in } \\
\text { eCRM profession }\end{array}$ & \\
\hline & $\mathrm{DA}_{3}$ & $\begin{array}{l}\text { The project team is capable of describing business processes and } \\
\text { make the request for processing on eCRM }\end{array}$ & \\
\hline & $\mathrm{DA}_{4}$ & $\begin{array}{l}\text { The project team is capable of coordinating with a team of } \\
\text { implementation consultants }\end{array}$ & \\
\hline & $\mathrm{DA}_{5}$ & $\begin{array}{l}\text { The project team has experience in implementing banking } \\
\text { information system solution project }\end{array}$ & \\
\hline \multirow{5}{*}{$\begin{array}{l}\text { Banking } \\
\text { culture }\end{array}$} & $\mathrm{VH}_{1}$ & $\begin{array}{l}\text { The staff always cooperate in the process of implementing and } \\
\text { operating the eCRM system }\end{array}$ & \multirow{5}{*}{$\begin{array}{l}\text { Apply with } \\
\text { adjusted } \\
\text { scale (Abd } \\
\text { El Kader, } \\
\text { 2012), } \\
\text { (Esmaeilpour } \\
\text { and Dashti, } \\
\text { 2013) }\end{array}$} \\
\hline & $\mathrm{VH}_{2}$ & $\begin{array}{l}\text { The staff is always willing to share with each other between the } \\
\text { individuals and the departments }\end{array}$ & \\
\hline & $\mathrm{VH}_{3}$ & $\begin{array}{l}\text { The staff is always well aware of the benefit and importance of } \\
\text { eCRM }\end{array}$ & \\
\hline & $\mathrm{VH}_{4}$ & $\begin{array}{l}\text { The process of coordination between the units is fully established, it } \\
\text { is clear, simple and well documented }\end{array}$ & \\
\hline & $\mathrm{VH}_{5}$ & $\begin{array}{l}\text { Individuals and units are towards the common goal of eCRM when } \\
\text { addressing issues arising }\end{array}$ & \\
\hline \multirow{5}{*}{$\begin{array}{l}\text { eCRM system } \\
\text { users }\end{array}$} & $\mathrm{SD}_{1}$ & The staff understand procedures for using eCRM system & \multirow{5}{*}{$\begin{array}{l}\text { Apply with } \\
\text { adjusted } \\
\text { scale } \\
\text { (Almotairi, } \\
\text { 2010) }\end{array}$} \\
\hline & $\mathrm{SD}_{2}$ & $\begin{array}{l}\text { The staff are in compliance with the implementing procedures } \\
\text { when using eCRM system }\end{array}$ & \\
\hline & $\mathrm{SD}_{3}$ & $\begin{array}{l}\text { The employees are well aware of their own influence on other } \\
\text { individuals, other parts when using eCRM system }\end{array}$ & \\
\hline & $\mathrm{SD}_{4}$ & $\begin{array}{l}\text { The employees are easy to adapt to the new technological } \\
\text { processes, new requirements }\end{array}$ & \\
\hline & $\mathrm{SD}_{5}$ & $\begin{array}{l}\text { The staffuse flexibly new technology application in professional } \\
\text { work }\end{array}$ & \\
\hline \multirow{5}{*}{$\begin{array}{l}\text { Data quality of } \\
\text { eCRM system }\end{array}$} & $\mathrm{DL}_{1}$ & Comprehensive customer data across all transaction channels & \multirow{5}{*}{$\begin{array}{l}\text { Apply with } \\
\text { adjusted } \\
\text { scale } \\
\text { (Almotairi, } \\
\text { 2010) }\end{array}$} \\
\hline & $\mathrm{DL}_{2}$ & $\begin{array}{l}\text { Customer data of the current system can convert in full and in } \\
\text { accordance with eCRM system }\end{array}$ & \\
\hline & $\mathrm{DL}_{3}$ & Customer data is always updated promptly and accurately & \\
\hline & $\mathrm{DL}_{4}$ & $\begin{array}{l}\text { Customer data is collected in full and in line with the needs of the } \\
\text { information user }\end{array}$ & \\
\hline & $\mathrm{DL}_{5}$ & The data is highly secure & \\
\hline \multirow{5}{*}{$\begin{array}{c}\text { IT } \\
\text { infrastructure }\end{array}$} & $\mathrm{HT}_{1}$ & IT infrastructurealways operates stably & \multirow{5}{*}{$\begin{array}{l}\text { Apply with } \\
\text { adjusted } \\
\text { scale } \\
\text { (Almotairi, } \\
\text { 2010) }\end{array}$} \\
\hline & $\mathrm{HT}_{2}$ & $\begin{array}{l}\text { The management systems across all transaction channels are } \\
\text { integrated together }\end{array}$ & \\
\hline & $\mathrm{HT}_{3}$ & There are storage systems and large data processing & \\
\hline & $\mathrm{HT}_{4}$ & There are systems to ensure data safety & \\
\hline & $\mathrm{HT}_{5}$ & IT infrastructure can be expanded and continuously updated & \\
\hline \multirow{2}{*}{$\begin{array}{l}\text { Inspection, } \\
\text { monitoring and } \\
\text { measurement }\end{array}$} & $\mathrm{KT}_{1}$ & $\begin{array}{l}\text { There is detailed plans to test, monitor and measure the process of } \\
\text { implementing eCRM }\end{array}$ & \multirow[b]{2}{*}{$\begin{array}{l}\text { Apply with } \\
\text { adjusted }\end{array}$} \\
\hline & $\mathrm{KT}_{2}$ & $\begin{array}{l}\text { Having set board ofinspection, monitoring and measurement for the } \\
\text { eCRM solutionimplementing process }\end{array}$ & \\
\hline
\end{tabular}




\begin{tabular}{|c|c|c|c|}
\hline & $\mathrm{KT}_{3}$ & There are meetings to track progress of eCRM implementation & \multirow{3}{*}{$\begin{array}{c}\text { scale } \\
\text { (Almotairi, } \\
\text { 2010) }\end{array}$} \\
\hline & $\mathrm{KT}_{4}$ & There are reports monitoring progress of eCRM implementation & \\
\hline & $\mathrm{KT}_{5}$ & $\begin{array}{l}\text { Having built the criteria to measure and control the cost, quality and } \\
\text { the objectives of eCRM }\end{array}$ & \\
\hline \multirow{5}{*}{$\begin{array}{l}\text { ECRM } \\
\text { Solution } \\
\text { success }\end{array}$} & $\mathrm{TC}_{1}$ & Quality of system & \multirow{5}{*}{$\begin{array}{c}\text { Apply } \\
\text { withadjusted } \\
\text { scale of } \\
\text { Gable and } \\
\text { coworker } \\
(2008)\end{array}$} \\
\hline & $\mathrm{TC}_{2}$ & Information Quality & \\
\hline & $\mathrm{TC}_{3}$ & Personal effects & \\
\hline & $\mathrm{TC}_{4}$ & Impact on banks & \\
\hline & $\mathrm{TC}_{5}$ & Overall success & \\
\hline \multirow{6}{*}{$\begin{array}{l}\text { Effectiveness } \\
\text { of customer } \\
\text { relationship }\end{array}$} & $\mathrm{HQ}_{1}$ & Overall effectiveness of customer relationship & \multirow{6}{*}{$\begin{array}{l}\text { Apply with } \\
\text { adjusted } \\
\text { scale of } \\
\text { Sivaraks and } \\
\text { coworker } \\
\text { (2011), } \\
\text { Maroofi and } \\
\text { coworker } \\
\text { (2012) }\end{array}$} \\
\hline & $\mathrm{HQ}_{2}$ & Customer Satisfaction & \\
\hline & $\mathrm{HQ}_{3}$ & Customer loyalty & \\
\hline & $\mathrm{HQ}_{4}$ & Customer trust & \\
\hline & $\mathrm{HQ}_{5}$ & Customer commitment & \\
\hline & $\mathrm{HQ}_{6}$ & The willingness of customer to introduce & \\
\hline
\end{tabular}

